\title{
Characterization of the biodegradable behavior for biphasic calcium phos- phates using X-ray diffraction and lattice parameter
}

\author{
Dong-Hyun Kim, Chang-Weon Song, Tae-Wan Kim, Heoyng-Ho Jin, Hong-Chae Park and Seog-Young Yoon ${ }^{\dagger}$ \\ School of Materials Science Enginnering, Pusan National University, Busan 609-735, Korea
}

(Received June 14, 2011)

(Revised June 25, 2011)

(Accepted July 15, 2011)

\begin{abstract}
Nanoscale-biodegradable behaviors of synthesized biphasic calcium phosphates (BCP) powders were characterized using X-ray diffraction (XRD), lattice parameter, and field emission microscopy (FE-SEM). The calcined BCP powders in vitro tested in Hank's balanced salt solution $\left(\mathrm{pH}=7.4,36.5^{\circ} \mathrm{C}\right)$ for 3 weeks. The calculated unit cell parameters for BCP have shown lattice distortion and expansion as irregular changes in the a and c-axis after in vitro.
\end{abstract}

Key words Biphasic calcium phosphate, X-ray diffraction, In vitro test, Lattice parameter

\section{X-선 회절 및 격자 매개변수를 이용한 biphasic calcium phosphate 분말의 생분 해성 특성평가}

김동현, 송창원, 김태완, 진형호, 박홍채, 윤석영

부산대학교 재료공학부, 부산, 609-735

(2011년 6월 14일 접수)

(2011년 6월 25일 심사완료)

(2011년 7월 15일 게재확정)

요 약 합성된 biphasic calcium phosphate(BCP) 분말의 나노크기 생분해성 거동은 $\mathrm{X}$-선 회절 분석방법, 격자 매개변수 및 전계방출형 주사전자현미경을 통해 특성평가 하였다. $\mathrm{BCP}$ 분말은 공침반응 및 하소과정을 통해 합성하였고, 합성된 분 말은 행크 용액 $\left(\mathrm{pH}=7.4,36.5^{\circ} \mathrm{C}\right)$ 을 이용하여 3 주 동안 in vitro 시험 하였다. 분해 시험(in vitro) 후, $\mathrm{BCP}$ 단위포의 매개변 수는 a 및 c축의 불규칙한 변화와 비슷한 격자 왜곡 및 팽창 거동을 보였다.

\section{1. 서 론}

Calcium phosphate계 세라믹스 재료는 생체와의 우수 한 친화력 및 골전도성으로 인하여 생체 의료용 재료로 서 각광을 받고 있으며, 특히 무기 결정 화합물인 합성 hydroxyapatite $\left(\mathrm{Ca}_{10}\left(\mathrm{PO}_{4}\right)_{6}(\mathrm{OH})_{2}\right.$, 이하 $\mathrm{HAp}$ 표기)와 $\beta$ tricalcium phosphate $\left(\beta-\mathrm{Ca}_{3}\left(\mathrm{PO}_{4}\right)_{2}\right.$, 이하 $\beta$-TCP 표기 $)$ 에 대한 연구는 신체 경조직(hard tissue) 대체 및 골수복재 (bone regeneration materials)에 관련하여 응용되고 있다 [1-6].

일반적으로 calcium phosphate계 세라믹스를 생체 내 에 식립(implant) 할 경우, $\mathrm{HAp}$ 는 비분해성을, $\beta$-TCP는

\footnotetext{
Corresponding author

Tel: +82-51-510-2487

Fax: +82-51-512-0528

E-mail: syy3@pusan.ac.kr
}

분해성을 가지는 것으로 알려져 있는 가운데 이러한 상반 된 분해거동을 동시에 가지는 biphasic calcium phosphate (이하 $\mathrm{BCP}$ 표기)의 생체 분해성과 활성의 조절은 $\mathrm{BCP}$ 의 구성 조직인 $\mathrm{HAp} / \beta-\mathrm{TCP}$ 의 상(phase) 비율 값에 의 해 좌우 될 수 있으며, 이러한 상 조절 능력에 따른 의 료용 재료로서의 적용연구가 진행 중이다[7].

생체 내 적용 연구에 있어 $\mathrm{BCP}$ 복합 조직의 분해특 성은 의사체액(simulated body fluid)에서 특성 평가하는 경우가 많은데, 이런 경우 분말의 분해 후 나타나는 의 사체액 내 $\mathrm{Ca}^{2+}$ 및 $\mathrm{PO}_{4}^{3+}$ 이온의 농도를 측정하여 $\mathrm{BCP}$ 분말의 분해거동을 예측하고 있다 $[8,9]$. 그러나 실질적 으로 생체 내 적용 후 $\mathrm{BCP}$ 자체의 특성평가가 아닌 용 액내의 화학적 분해거동에만 초점이 맞추어 있는 실정이 며, in-vitro 및 in-vivo 시험에 적용된 $\mathrm{BCP}$ 분말의 결정 학적 측면에 관한 연구는 미비한 실정이다.

따라서 본 연구에서는 합성된 $\mathrm{BCP}$ 분말을 in vitro 
테스트 한 후, 적용된 분말의 분해시간에 따른 $\mathrm{HAp} / \beta$ $\mathrm{TCP}$ 상 비율을 측정하였고, 결정학적 격자 매개변수 (crystallographic lattice parameter)를 측정하여 나노스케 일에서의 $\mathrm{BCP}$ 분말의 분해거동을 연구하고자 한다.

\section{2. 실험방법}

본 연구에서 Biphasic Calcium Phosphate(BCP)를 제 조하기 위해 시약급의 $\mathrm{Ca}\left(\mathrm{NO}_{3}\right)_{2} \cdot 4 \mathrm{H}_{2} \mathrm{O}(\mathrm{KATAYAMA}$ Chemical, Japan)과 $\left(\mathrm{NH}_{4}\right)_{2} \mathrm{HPO}_{4}(\mathrm{JUNSEI}$ Chemical, Japan)을 공침 및 하소처리과정을 통해 합성하였다. $\mathrm{BCP}$ 분말의 합성조건은 선행실험 결과에 근거하여 목표 한 $\mathrm{HAp}$ 와 $\beta-\mathrm{TCP}$ 의 $60: 40$ 비율이 되기 위해 $\mathrm{Ca}\left(\mathrm{NO}_{3}\right)_{2}$. $4 \mathrm{H}_{2} \mathrm{O}$ 와 $\left(\mathrm{NH}_{4}\right)_{2} \mathrm{HPO}_{4}$ 를 $\mathrm{Ca} / \mathrm{P}$ 몰 비 1.602 에 맞추어 정 량하였다. $250 \mathrm{~m}$ 의 탈이온 증류수(Distilled water)에 $\mathrm{Ca}\left(\mathrm{NO}_{3}\right)_{2} \cdot 4 \mathrm{H}_{2} \mathrm{O}$ 및 $\left(\mathrm{NH}_{4}\right)_{2} \mathrm{HPO}_{4}$ 을 첨가한 후 $\mathrm{NH}_{3}(\mathrm{JUNSEI}$ Chemical, Japan)를 천천히 적가하여 $\mathrm{pH} 11$ 로 조절 하 여 공침시켰다.

이렇게 제조된 현탁액을 2 시간 동안 교반을 한 후 상 온에서 24시간 동안 시효처리(Aging)하였다. 반응생성물 의 여과 및 미 반응물을 제거하기 위해 $1 \mu \mathrm{m}$ 의 미세필 터를 이용하여 증류수로 최소한 5 회 이상 반복적으로 수세하였다. 여분의 수분을 제거하기 위하여 $80^{\circ} \mathrm{C}$ 로 고 정된 건조기를 이용하여 24 시간 동안 충분히 건조시켰 다. 이렇게 얻은 분말을 충분히 분쇄 및 400 mash 체가 름 후, 전기로를 이용하여 $900^{\circ} \mathrm{C}$ 에서 2 시간 동안 하소 처리 하여 $\mathrm{BCP}$ 분말을 제조하였다. $\mathrm{BCP}$ 분말의 생체 활성 평가를 위하여 행크 용액 $\left(\mathrm{pH}=7.4,36.5^{\circ} \mathrm{C}\right)$ 에 3 주 간 침적 시켰다.

제조된 $\mathrm{BCP}$ 분말 및 in vitro 시험을 거친 시편은 $\mathrm{XRD}$ (D/max-IIA, Rigaku)를 사용하여 X-선 회절패턴 값을 측정하였고, 생성물의 상 분석 및 격자 매개변수는 X'Pert High Score(PANalytical B.V.) 프로그램을 분석하였고, ICDD(The International Centre for Diffraction Data) 데이터베이스(HAp; 00-009-0432, $\beta$-TCP; 00-009-0169) 를 통해 계산하였다. 또한 FE-SEM(S-4800, Hitachi)을 통해 분해시간에 따른 입자형상 및 분해 진행과정을 관 찰하였다.

\section{3. 결과 및 고찰}

3.1. In vitro 시험에 따른 biphasic calcium phosphate 의 분해 거동

출발 물질의 $\mathrm{Ca} / \mathrm{P}$ 몰 비율을 1.602 로 고정하여 합성한

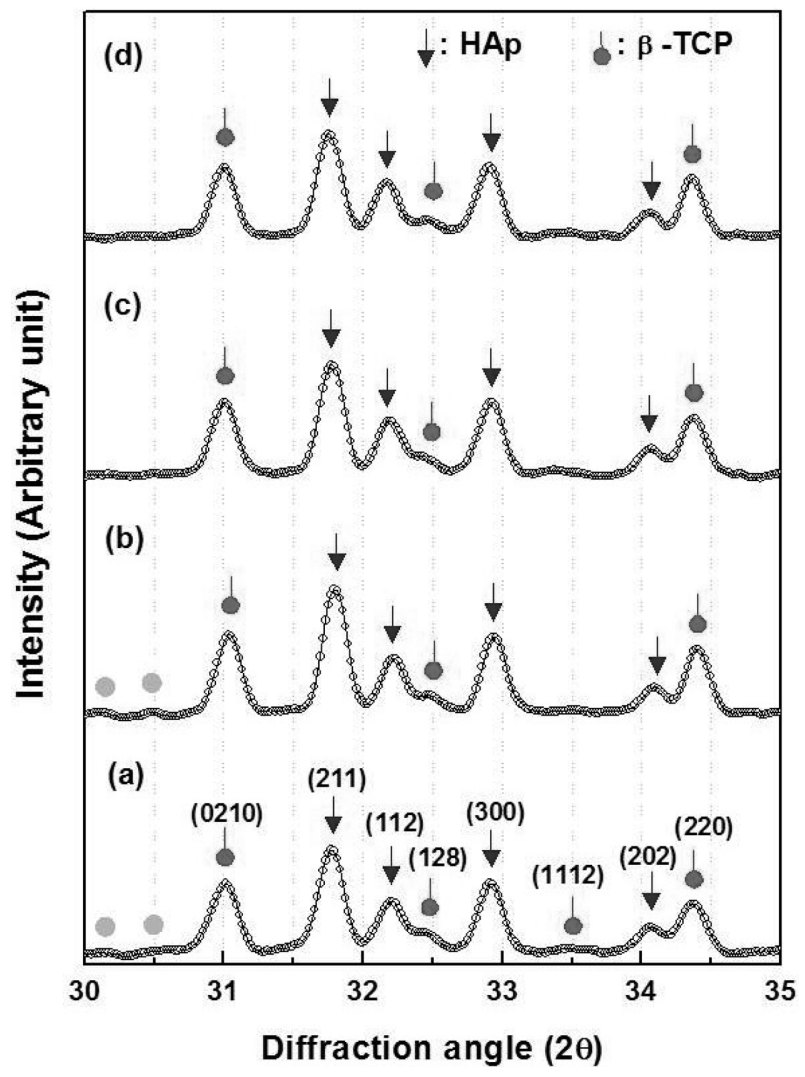

Fig. 1. XRD patterns of BCP powders obtained after in vitro test; (a) 0, (b) 1, (c) 2, and (d) 3 week.

$\mathrm{BCP}$ 분말을 행크 용액에서 3 주간 in vitro 실험한 결과 를 Fig. 1 및 2에 나타내었다. Fig. 1은 in vitro 분해 실험 후 얻어진 분말의 XRD 회절패턴 결과이다. In vitro 분해시험 후 얻어진 분말의 결정상은 각각 $\beta$-TCP 와 HAp 피크가 혼재한 이상(biphasic)이 관찰 되었으며, 각각의 주 피크인 HAp (211)와 $\beta-\mathrm{TCP}$ (0210) 피크는 분해 시간에 따라 뚜렷하게 양분화 되었다. 게다가 HAp 주 피크는 분해 시험 1 주 후에는 오히려 성장하다가 2 주 후에는 다시 감소함을 관찰 하였다. 또한 합성된 분 말의 미반응물로 사료되는 피크(index; grey circle)는 분 해 시간에 따라 관찰이 되지 않았다.

Fig. 2는 합성된 $\mathrm{BCP}$ 및 in vitro 분해 시험 후 얻어 진 분말 표면의 SEM 결과이다. 행크 용액에 의한 분해 실험 후 회수된 분말형상은 합성된 $\mathrm{BCP}$ 분말 보다 상 대적으로 분해된 형상을 보였고, 열처리에 의해 생성된 기공수도 분해시간에 따라 작아짐을 관찰하였다. 이러한 경향은 Fig. 1의 결과와 비교하여 볼 때, 공침법에 의해 합성된 분말(저 결정성 $\mathrm{HAp}$ 생성 확인)은 열처리 $\left(900^{\circ} \mathrm{C}\right)$ 에 의해 $\mathrm{BCP}$ 상으로 합성되나 공침분말의 비화학양론비 에 의해 $\mathrm{Ca}$ 결손 apatite 및 분해성 calcium phosphate 조직이 미약하게 생성되어 행크 용액 내에서의 유지시간 에 따라 표면에서부터 분해되어 생성된 결과라 사료된다. 

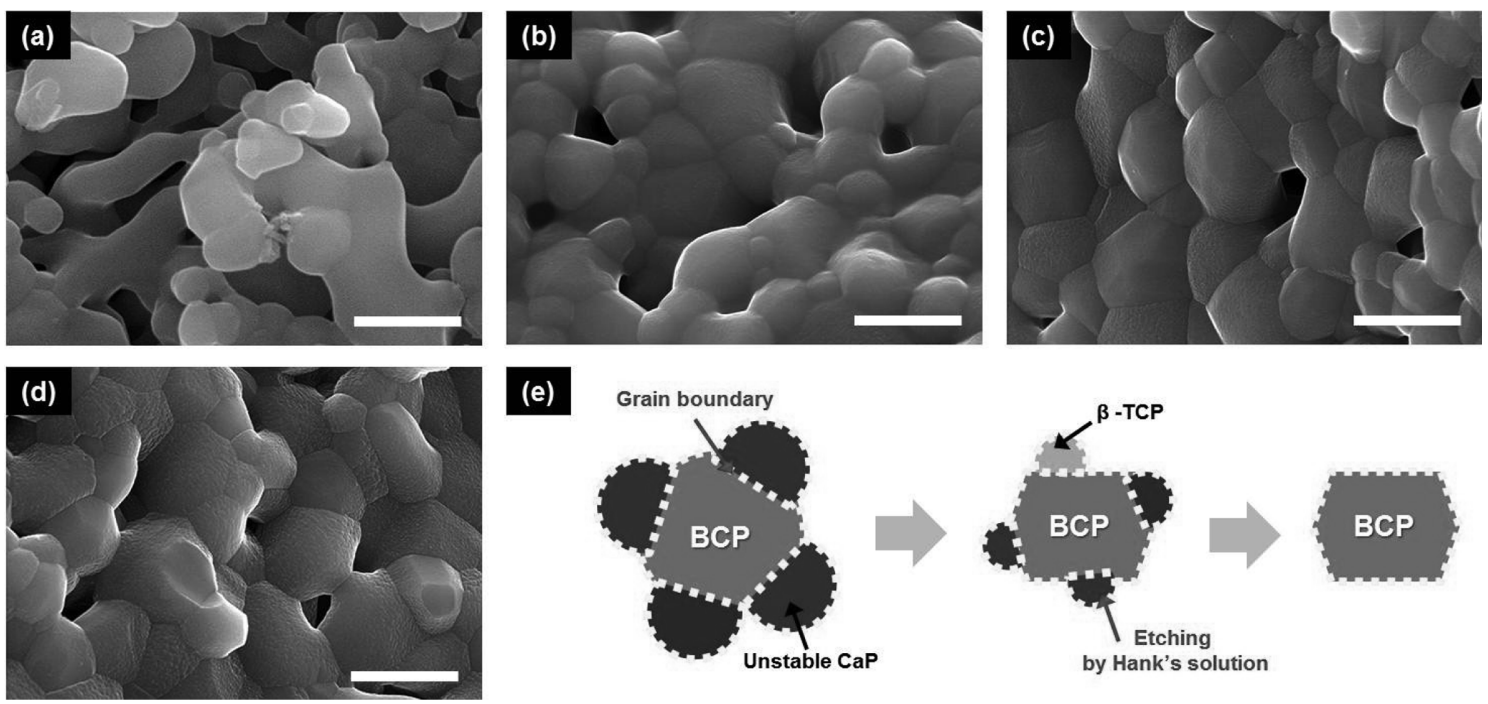

Fig. 2. SEM images of BCP powders obtained after in vitro test; (a) 0 , (b) 1 , (c) 2 , and (d) 3 week (Scale bar is $1 \mu \mathrm{m}$ ). Fig. 2 (e) shows schematics for biodegradable behaviors of BCP in micro-scale.

3.2. In vitro 시험에 따른 biphasic calcium phosphate 의 상 거동 관찰

\section{행크 용액에서 3주간 in vitro 시험한 $\mathrm{BCP}$ 분말시편} 의 $\mathrm{XRD}$ 회절패턴 중 $\beta-\mathrm{TCP}$ 와 $\mathrm{HAp}$ 상의 주 피크를 이 용하여, 분해시간에 따른 상변화 거동을 관찰한 결과를 Fig. 3에 나타내었다. 이 때 $\beta-\mathrm{TCP}$ 와 $\mathrm{HAp}$ 상 주 피크의 적분강도 값을 구하기 위해 각각의 피크를 분리시켜 분 석하였다(Fig. $3 \mathrm{a}$ 참조). Fig. $3(\mathrm{~b} \sim \mathrm{d})$ 결과에 있어, $\beta$ -
$\mathrm{TCP}$ 상의 피크 강도 값은 유지되었으나 $\mathrm{HAp}$ 상의 피크 강도 값은 시간에 따라 증가하다가 다시 감소하였다. 그 러나 FWHM(full width at half maximum)값은 시간에 따라 $\mathrm{HAp}$ 상은 증가하다가 유지 되었으며, $\beta$-TCP상의 $\mathrm{FWHM}$ 값은 감소하였다. 이를 기초로 상대적인 피크 강도 값(HAp 피크강도 값을 $100 \%$ 로 기준함)을 구한 결과, $\beta$-TCP상의 피크 강도 값은 분해시간에 따라 감소 함을 알 수 있었다. 또한 Fig. 3a 그래프를 이용하여 적 분강도 값을 구하여 상대적인 상 비율을 구한 결과, 분해 (a)

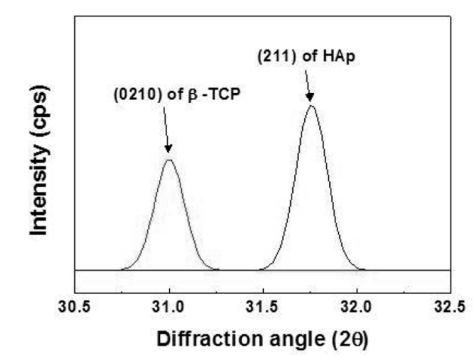

(d)

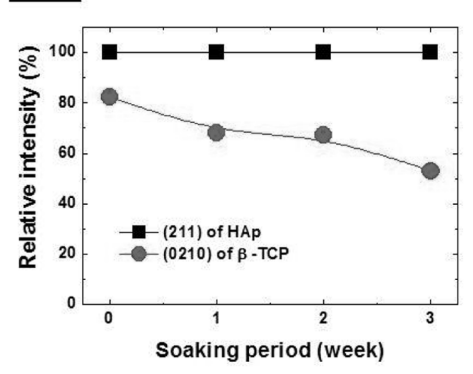

(b)

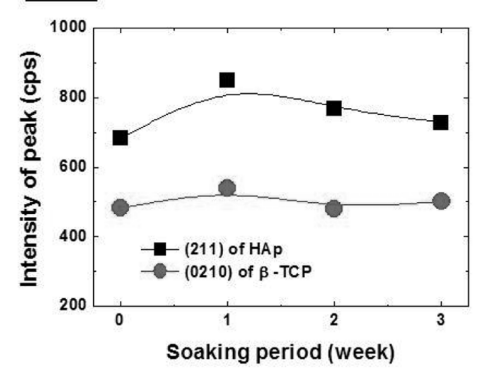

(e)

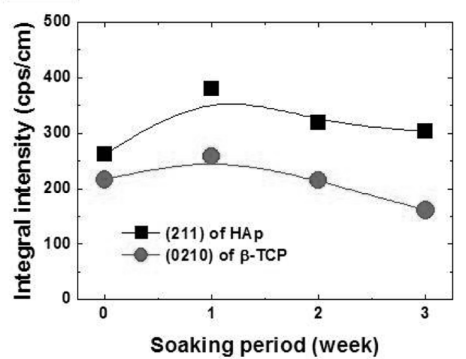

(c)

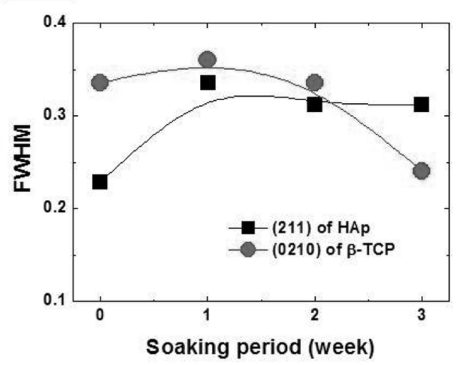

(f)

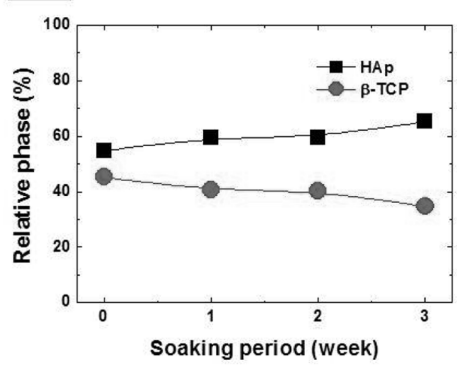

Fig. 3. Phase analysis of BCP powders obtained after in vitro test; (a) main peak of BCP pitted by gaussian function, (b) XRD peak intensity, (c) FWHM, (d) relative intensity, (e) Integral intensity, and (e) relative phase ratio of HAp and $\beta$-TCP. 
시간에 따라 $\mathrm{HAp}$ 상은 증가하였고, $\beta$-TCP상은 감소하였 다(Fig. 3e 및 f). 이러한 연구결과를 바탕으로 상반된 분해거동을 동시에 가지는 $\mathrm{BCP}$ 는 생체 내 구조적 안정 성 $(\mathrm{HAp})$ 과 생분해 거동을 가진다고 판단되어 진다.

\subsection{Biphasic calcium phosphate의 나노크기 분해 거동}

Fig. 4와 5는 행크 용액에서 3 주간 in vitro 시험한 $\mathrm{BCP}$ 분말시편의 분해시간에 따른 $\mathrm{HAp}$ 및 $\beta$-TCP unit cell의 lattice parameter 결과 값이다. Unit cell의 lattice parameter 결과 값은 $\mathrm{ICDD}$ (The International Centre for Diffraction Data) reference(HAp; 00-009-0432, $\beta$ $\mathrm{TCP}$; 00-009-0169)와 측정된 XRD 회절패턴 값(면 지 수)을 이용하여 각각의 상에 대한 d-spacing 값의 변이 차를 구하여 계산하였다.

Fig. 4에서 나타낸 HAp의 hexagonal 구조 unit cell에 있어 $\mathrm{a}$ 축 길이는 분해 시간에 따라 증가 하다가 다시 감소하였고, $\mathrm{c}$ 축 길이는 감소하다가 점진적으로 증가 하였다. 분해실험 전 $\mathrm{HAp}$ 상의 $\mathrm{a} / \mathrm{c}$ 축비는 이상적인 hexagonal 구조 $(\mathrm{a} / \mathrm{c}$ ratio $=1.368)$ 와 비슷한 구조를 가졌 으나, 분해시간에 따라 $\mathrm{a}$ 축 길이가 증가하다가 이론적 인 $\mathrm{a} / \mathrm{c}$ 축비에 가까워짐을 알 수 있었다. 또한 $\mathrm{HAp}$ unit cell의 부피는 이론 값 보다 작은 부피를 가졌지만 분해시간에 따라 이론값에 가까워짐을 알 수 있었다.

이와 달리 Fig. 5에 나타낸 바와 같이 $\beta$-TCP unit cell의 lattice parameter 결과는 분해 실험 전 시편의 rhombohedral 구조에 있어, a 및 $\mathrm{c}$ 축의 길이는 이론값 에 비해 감소된 상태였다. 분해시간에 따라 $\mathrm{a}$ 및 $\mathrm{c}$ 축의 길이는 이론값에 가까워지고 있으나 $\mathrm{a} / \mathrm{c}$ 축비는 전반적 으로 이론값에 비해 상대적으로 벗어나 있음을 알 수 있 었다. 그러나 $\beta-\mathrm{TCP}$ unit cell의 부피는 분해시간에 따 라 증가하다가 이론값에 가까워짐을 알 수 있었다.

3.4. Biphasic calcium phosphate의 나노크기 생분해 메커니즘

상기 열거된 Fig. 1 5의 결과에 의해 $\mathrm{BCP}$ 분말의 분 해거동은 Fig. 6과 같이 설명 할 수 있다. 첫째, $\mathrm{HAp}$ 및 $\beta$-TCP의 unit cell parameter 중, 축각(axial angle)은 기본적으로 같으나 $\left(a=\beta=90^{\circ}, \gamma=120^{\circ}\right)$ 축 길이 및 결 정방향이 서로 다르기 때문에 lattice mismatch가 생길 가능성이 크다. 둘째, 다결정상의 입자에 있어 하나의 입 자는 $\mathrm{HAp}$ 및 $\beta$-TCP 단결정상이 존재하고, 결정방향이 서로 다르기 때문에 입내에서 응력은 발생 하지 않는다
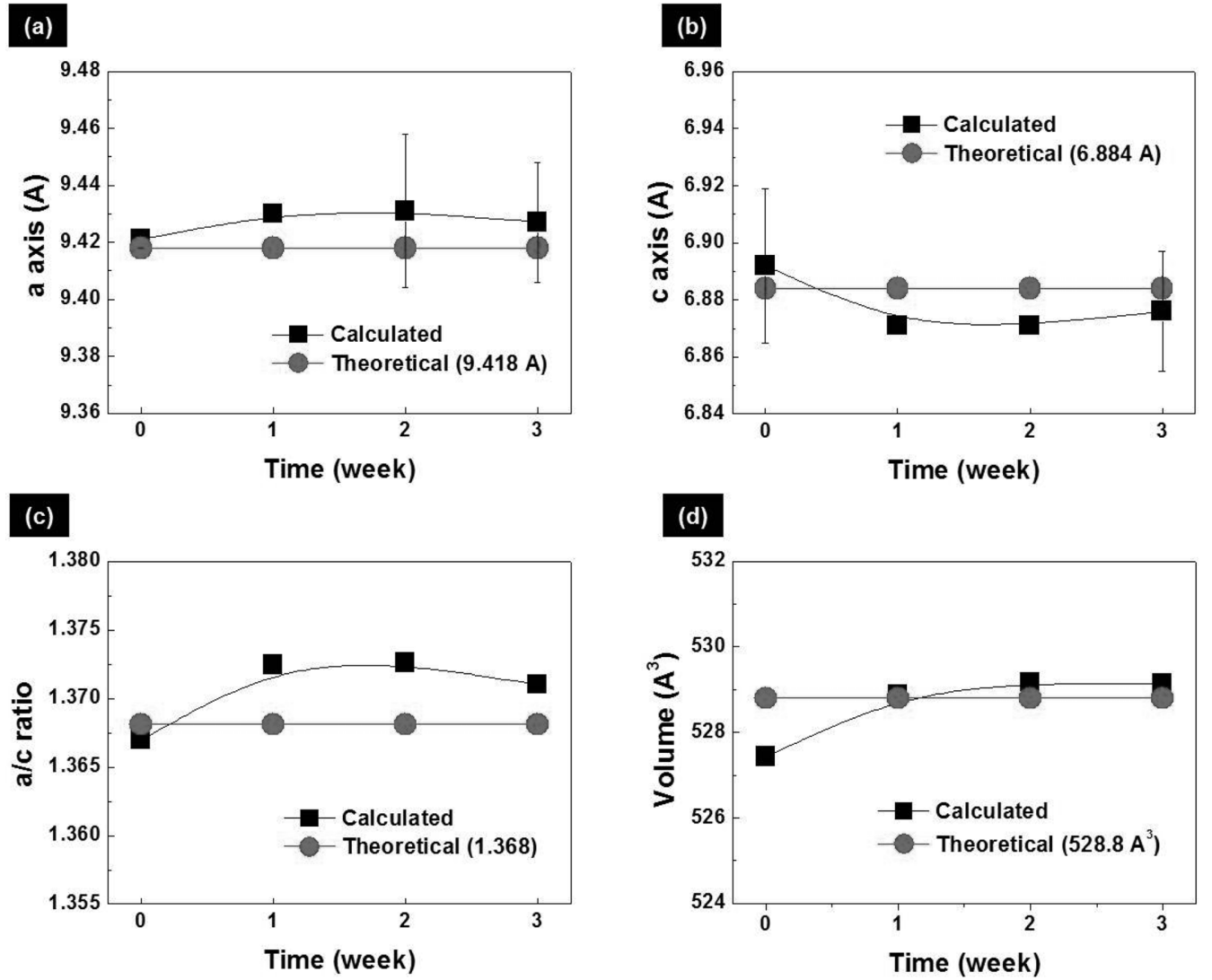

Fig. 4. Lattice parameter of hexagonal HAp unit cell calculated from BCP powders obtained after in vitro test; (a) a-axis, (b) c-axis, (c) a/c ratio, and (d) volume (Notice: $a=b$-axis, $a=\beta=90^{\circ}, \gamma=120^{\circ}$ ). 


\section{(a)}

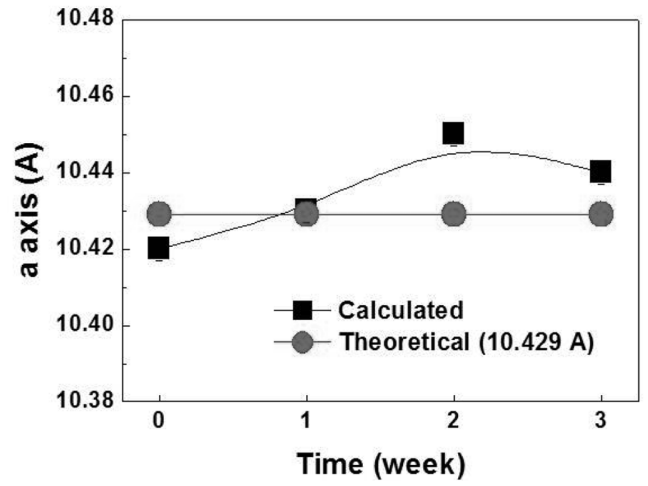

\section{(c)}

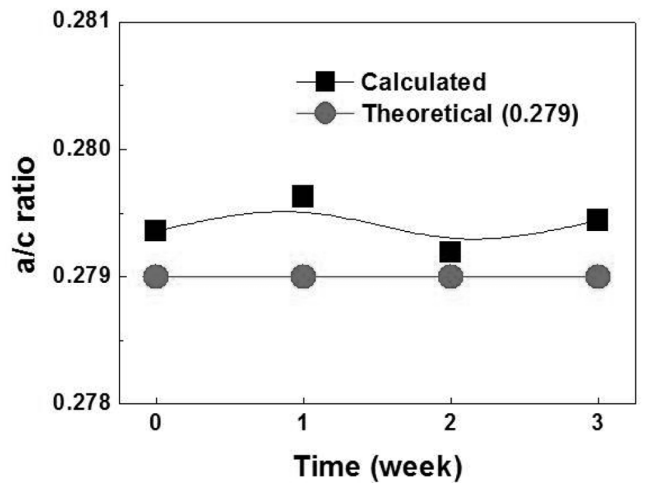

(b)

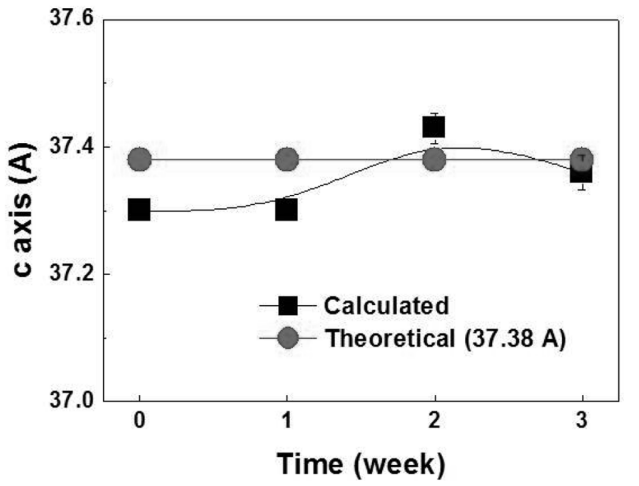

(d)

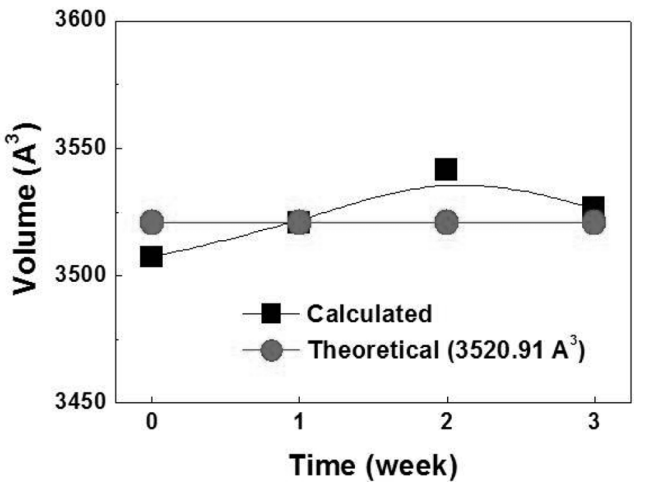

Fig. 5. Lattice parameter of rhombohedral $\beta$-TCP unit cell calculated from BCP powders obtained after in vitro test; (a) a-axis, (b) c-axis, (c) a/c ratio, and (d) volume (Notice: $\mathrm{a}=\mathrm{b}$-axis, $a=\beta=90^{\circ}, \gamma=120^{\circ}$ ).
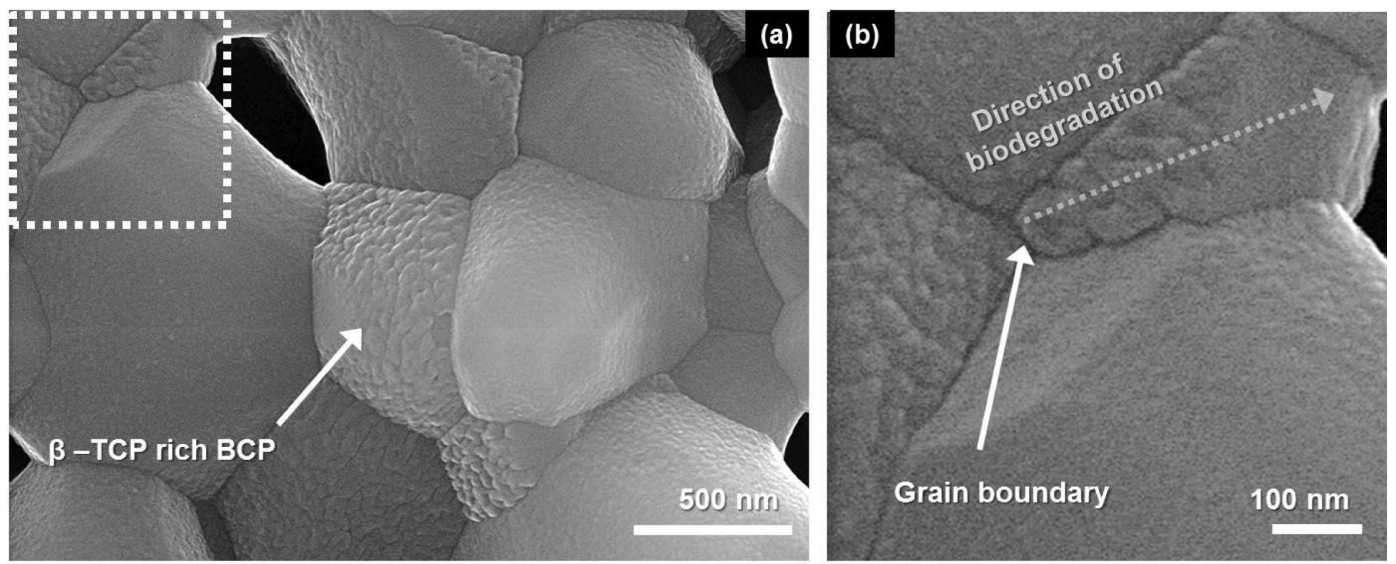

\section{(c)}
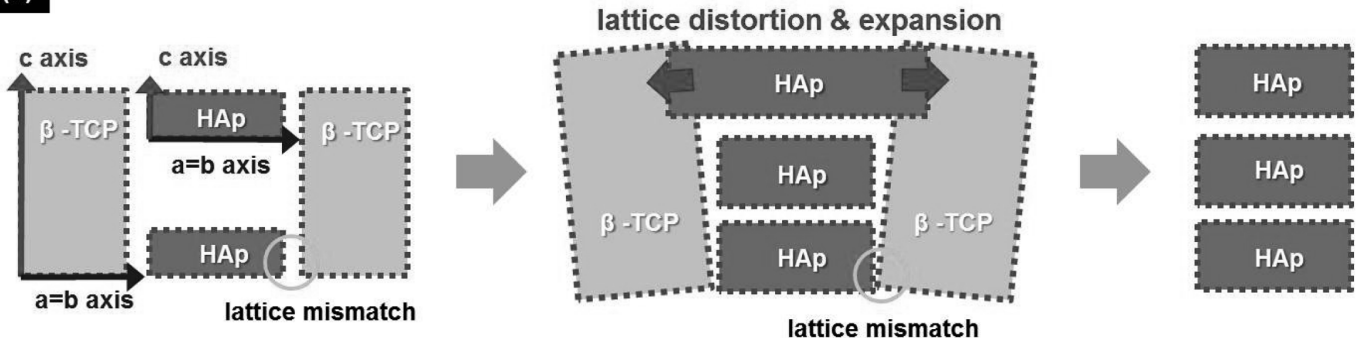

Fig. 6. Biodegradable behaviors of BCP in nano-scale; ( $a$ and b) FE-SEM results of BCP after in vitro for 3 week (Fig. 6(b) shows an inset image is magnified from the dotted line of Fig. 6(a)), (c) schematics for biodegradable behaviors of HAp and $\beta$-TCP unit cell (Notice: $\mathrm{a}=\mathrm{b}$-axis, $a=\beta=90^{\circ}, \gamma=120^{\circ}$ ). 
고 본다. 따라서 Fig. 1 5의 결과에서 유추 한다면 $\mathrm{BCP}$ 의 분해거동은 입계에서 시작되며, $\mathrm{HAp}$ 와 $\beta-\mathrm{TCP}$ 의 계 면(혹은 입계)에 결정학적으로 불안정한 상(예; bio glass 또는 $\mathrm{Ca}$-결손 apatite)이 존재하여 in vitro 분해시험 진 행시 행크 용액의 $\mathrm{pH}$ 불균형으로 인한 $\mathrm{Ca}$ 이온 방출 및 그에 따른 unit cell의 lattice distortion 및 expansion 에 의해 시간에 따라 분해가 가속화 될 가능성이 높다고 사료되어진다(Fig. 6(b) 참조). 셋째, Fig. 6(a)에 나타낸 결과에서 실질적으로 합성된 $\mathrm{BCP}$ 의 입자들은 $\mathrm{Ca} / \mathrm{P}$ 몰 비는 비화학양론비가 성립되기 때문에 $\beta$-TCP상이 상대 적으로 많은 $\mathrm{BCP}$ 조직 $(\beta-\mathrm{TCP}$ rich $\mathrm{BCP})$ 에서의 먼저 분해 될 수 있다고 판단되어진다.

\section{4. 결 론}

본 연구에서는 합성한 $\mathrm{BCP}$ 분말을 in vitro 분해시간 에 따라 $\mathrm{HAp} / \beta-\mathrm{TCP}$ 상 거동, 비율 및 결정학적 격자 매 개변수를 측정하였다. 상 비율 측정 결과, $\mathrm{BCP}$ 분말은 분해 시간에 따라 $\mathrm{HAp}$ 상은 증가하였고, $\beta$-TCP 상은 감 소하였다. 격자 매개변수를 측정에 있어, hexagonal $\mathrm{HAp}$ 격자구조는 분해시간에 따라 a 축 길이가 증가하 다가 이론적인 $\mathrm{a} / \mathrm{c}$ 축비에 가까워짐을 알 수 있었다. 이 와 달리 rhombohedral $\beta$-TCP 격자구조는 분해시간에 따라 unit cell 형태가 불규칙적으로 바뀌고 있음을 알 수 있었다. 나노스케일에서의 $\mathrm{BCP}$ 분해거동은 hexagonal HAp 격자구조와 rhombohedral $\beta$-TCP 격자간의 lattice mismatch 거점으로 분해 요인이 되며, 행크 용액에 의한 분말 표면에서의 $\mathrm{Ca}$ 이온의 방출에 의해 각각의 hexagonal 및 rhombohedral 구조가 lattice distortion 및 expansion 거동이 반복되기 때문에 분해가 이루어진다고 사료된다. 또한 이러한 분해의 시작은 grain boundary에서 진행됨 을 형상 관찰을 통해 유추 할 수 있었다. 이러한 연구결 과를 바탕으로 상반된 분해거동을 동시에 가지는 $\mathrm{BCP}$ 는 생체 내 구조적 안정성 $(\mathrm{HAp})$ 과 생분해 거동을 통한 생체 활성도 $(\beta-\mathrm{TCP})$ 를 가진다고 판단되어 진다.

\section{감사의 글}

이 논문은 2010년도 정부(교육과학기술부)의 재원으로 한국연구재단의 기초연구사업 지원을 받아 수행된 것임 (20100280000). 또한 본 연구는 교육과학기술부와 한국연 구재단의 지역혁신 인력양성사업으로 수행된 연구결과임.

\section{참 고 문 헌}

[ 1 ] K.-B. Park, J.-W. Park, H.-U. Ahn, D.-J. Yang, S.-K. Choi, I.-S. Jang, S.-I. Yeo and J.-Y. Suh, "Comparative study on the physicochemical properties and cytocom patibility of microporous biphasic calcium phosphate ceramics as a bone graft substitute", Journal of Periodontal \& Implant Science 36 (2006) 797.

[2] R.W. Bucholz, A. Carlton and R.E. Holmes, "Hydroxyapatite and tricalcium phosphate bone graft substitutes", Orthop. Clic. North Am. 18 (1987) 323.

[3] W. Suchanek and M. Yoshimura, "Processing and properties of hydroxyapatite-based biomaterials for use as hard tissue replacement implants", J. Mater. Res. 13 (1998) 94.

[4] Y. Ota, T. Iwashita, T. Kasuga, Y. Abe and A. Seki, "Bone formation following implantation of fibrous compounds $\left(\beta-\mathrm{Ca}\left(\mathrm{PO}_{3}\right)_{2}, \mathrm{CaCO}_{3}\right.$ (aragonite) $)$ into bone marrow", J. Mater. Sci. 12 (2002) 895.

[ 5 ] J.H. Kim, Y.M. Park, T.Y. Yang, S.Y. Yoon and H.C. Park, "Microstructural develpment in synthetic hydroxyapatite", J. Kor. Ceram. Soc. 41 (2004) 289.

[6] D.J. Baek, T.Y. Yang, Y.B. Lee, S.Y. Yoon and H.C. Park, "Fabrication of hydroxyapatite whiskers by hydrolysis of $\alpha$-TCP", J. Kor. Ceram. Soc. 40 (2003) 608.

[ 7 ] S.H. Kwon, Y.K. Jun, S.H. Hong and H.E. Kim, "Synthesis and dissolution behavior of $\beta$-TCP and HA/ $\beta$ TCP composite powders", J. Eur. Ceram. Soc. 23 (2003) 1039.

[ 8 ] R. Xin, Y. Leng, J. Chen and Q. Zhang, "A comparative study of calcium phosphate formation on bioceramics in vitro and in vivo", Biomaterials 26 (2005) 6477.

[9] S.-H. Kwon, Y.-K. Jun, S.-H. Hong and H.-E. Kim, "Synthesis and dissolution behavior of $\beta$-TCP and HA/ $\beta$-TCP composite powders", J. Euro. Ceram. Soc. 23 (2003) 1039. 